\title{
Product types in moderating the process of buying street foods
}

\author{
Budhi Haryanto, Djoko Purwanto, \& Amina Sukma Dewi \\ Universitas Sebelas Maret, Surakarta, Indonesia
}

\begin{abstract}
This study aims to examine the effects of price, quality, and ease in obtaining on positive attitudes and intentions to buy street food moderated by product types (traditional meals and modern meals). The sample consists of 1000 individuals. Multi-group SEM is a statistical tool selected to elaborate the relationships between variables that are conceptualized. The results indicate that before the product type is separated, price and quality are the variables that influence the positive attitude and the intention of buying the traditional food, while the ease of getting not. When this type of product is separated, the results indicate that in snack foods, the price, quality and ease of obtaining are the variables that affect the positive attitude, but do not affect the purchasing intentions. For restaurant food, that price and quality are the variables that influence positive attitude and purchase intention, while not for purchase intention.
\end{abstract}

Keywords: consumer behavior, positive attitude, purchase intention

\section{INTRODUCTION}

In Indonesia, the business on street food is just becoming a trend. This marked the number of street food businesses that have sprung up almost in every city in Indonesia.

Many journals of behavioral that reveal the local brand or who reveal about street food, but still relatively few who distinguish the behavioral process based on the type of food sold, namely are traditional food and modern food as the topics of study ( $\mathrm{Su}-$ lek \& Hensley 2004, Torres \& Kline, 2006).

There are 3 variables that can be conceptualized influence positive attitude and intention of purchasing street foods, namely product price, quality of product, and ease in obtaining product. This study wants to examine the influence of these 3 variables on positive attitude and intention to buy towards street foods. This study also examines the moderation effect of product type (traditional street foods and modern street foods) in buying process of street foods.

In the context of behavior, price is something that is sacrificed to obtain a product (Ayres \& Nalebuff 2003, De-Matos et al. 2007, Catoiu 2010). Frequently that price is used as predictor of quality, that is if the price of a brand is high, the quality of that brand is also high, this is also called the reasonableness of price. In the behavioral process, price fairness is conceptually positively related to purchasing decisions, meaning the higher the fairness of the price, the higher the decision to buy against the product (Campbell 1999, Vaidyanathan \& Aggarwal 2003, Xia et al. 2004, Haryanto \& Budiman 2016).

In this study, price is the main variable that is considered by the individual in determining the choice of street food. Individuals tend to prefer relatively cheap prices for traditional food, and are otherwise relatively expensive for modern foods (Delafrooz \& Paim 2011, Harcar et al. 2012, Beneke et al. 2013, Haryanto et al 2015).

Hypothesis 1: there is positive relationship between the fairness of price and the positive attitude toward the street foods.

Hypothesis 2: there is positive relationship between the fairness of price and intention to buy the street foods.

Hypothesis 3: the type of product moderates the relationship between the fairness of price and the positive attitude toward the street foods.

Hypothesis 4: the type of product moderates the relationship between the fairness of price and intention to buy the street foods. 
Previous studies indicate a variety of opinions about product quality. The first argument explains that product quality is independent of profit margins, another argument reveals the quality of the product from a marketer's perspective that is always associated with the specifications, features, functions or performance of a product (Van-Trijp et al. 1996). The next argument is that product quality is defined as superiority or superiority in a product when compared to an alternative product viewed from a market standpoint (Mittal et al. 1998).

In the context of behavior, it is hypothesized here that product quality is positively associated with purchasing decisions (Weiss et al. 2004). This means that the higher the quality of the product the higher the positive attitude towards the product. In addition to a positive attitude, product quality is conceptualized in relation to purchasing intentions (Munger \& Grewal 2001, Beneke et al. 2013, Kordnaeji et al. 2013).

In the context of street food products, food quality is become the next consideration to determine the buying decisions. Product quality in question is related to taste, uniqueness, presentations, and service provided. For traditional street food, the individual tends to emphasize the taste and distinctiveness of the cuisine in accordance with certain areas, whereas for modern street food, it tends to emphasize practicality in addition to other considerations (see Munger \& Grewal 2001, Beneke et al. 2013, \& Kordnaeji et al. 2013).

Hypothesis 5: there is positive relationship between the product quality and the positive attitude toward the street foods.

Hypothesis 6: there is positive relationship between the product quality and intention to buy the street foods.

Hypothesis 7: the type of product moderates the relationship between the product quality and the positive attitude toward the street foods.

Hypothesis 8: the type of product moderates the relationship between the product quality and intention to buy the street foods.

The ease in obtaining the product taken first from the term of comfort. Previous studies indicated some notions of convenience. First, convenience is defined as the capacity of an individual to use all resources efficiently to obtain the product (Nickols \& Fox 1983, Gofton \& Ness 1991, Scholderer \& Grunert 2005). This convenience means the ease of getting goods or to shop for products. Second, convenience is defined as the ease of use of the product (Verlegh \& Candel 1999, Scholderer \& Grunert 2005). In this study, the convenience in question is the ease of product acquisition that involves various sacrifices, whether in the form of money, time, physical, psy- chological to obtain a product (Thom 2007, Delafrooz \& Paim 2011, Harcar \& Yucelt 2012).

In this study, the concept building is the higher the easy in obtaining the product, the higher the positive attitude and the intention of buying the product (Thom 2007, Delafrooz \& Paim 2011, Harcar \& Yucelt 2012, Dehghanan \& Bakhshandeh 2014). Ease in getting road products is one of the considerations also in determining the choice of street food purchases. The primary reason for choosing street food is the ease in obtaining the foods, so it is responded by street food vendors to try to get the place of sale that is considered strategic for consumers (Thom 2007, Delafrooz \& Paim 2011, Harcar \& Yucelt 2012, Dehghanan \& Bakhshandeh 2014).

Hypothesis 9: there is positive relationship between easy in obtaining the product and the positive attitude toward the street foods.

Hypothesis 10: there is positive relationship between easy in obtaining the product and intention to buy the street foods.

Hypothesis 11: the type of product moderates the relationship between easy in obtaining the product and the positive attitude toward the street foods.

Hypothesis 12: the type of product moderates the relationship between easy in obtaining the product and intention to buy the street foods.

This study uses a positive attitude and purchase intention as a predictor of consumer behavior (Dodds et al. 1991, Delafrooz \& Paim 2011, Harcar \& Yucelt 2012, Beneke et al. 2013). As a predictor, both variables are often used as market size, as a result of the magnitude of potential demand for the product. Marketers will be very careful in making strategies in shaping and improving the positive attitude and purchase intentions of a product. In the process of behavior, there is a positive relationship between positive attitudes toward brands and brand buying intentions (Mitchell \& Olson 1981, Simonin \& Ruth 1998, Haryanto 2014).

Hypothesis 13: The higher the positive attitude toward the street food, the higher the buying intention towards street foods.

\section{RESEARCH METHODS}

The population of this study is people interested in street foods. There are 2 samples taken are 500 people prefer to traditional street food, and 500 people who prefer modern street foods. The way data is collected is to question people in public areas, without coercion. Next the questionnaire is given to be filled in, and immediately withdrawn when all items are filled in all. The Multiple Group Structural 
Equation Model (Multi Group SEM) is a statistical tool selected to test the conceptual hypothesis (Bou \& Satorra 2010).

The product price is defines as the individual's perception of the fairness of the price. The variables are measured by: fairness, openness, correspondence, rationality, logic. The product Quality is an individual perception of the superiority of a product's quality. This variable is measured by ease, privilege, freshness, excellence, cleanliness. The ease in obtaining the product is defined as the individual's perception of the level of effort sacrificed in obtaining a product. This variable is measured with overpriced, congestion, exhaustion, stress, and aggravation. The positive attitude is defined as feeling like or happy about a product. Furthermore, positive attitudes are measured by joy, joy, pleasure, positive thoughts, enthusiasm. The purchase intent is defined as the individual's desire to buy a product. The variable is measured by the items: probability, will, tendency, interest, desire. All of the items are measured using a five-level Likert scale: (1) strongly disagree, (2) disagree, (3) neutral, (4) agree, and (5) strongly agree. While the product type is measured using two categorical scales: (1) traditional street foods and (2) modern street foods.

\section{RESULTS AND DISCUSSIONS}

\subsection{The Price Fairness as Stimulus}

The relationship between the fairness of price and positive attitude toward street foods is significant and positive $(\beta=.284 ; \mathrm{SE}=.051 ; \mathrm{CR}=5.545)$. As well as the relationship between product price and intention to buy the street foods is significant and positive $(\beta=.121 ; \mathrm{SE}=.044 ; \mathrm{CR}=2.738)$. So the hypothesis 1 and hypothesis 2 are supported. It means the higher the perception of the fairness of price the higher the positive attitude towards street foods and intention to buy the street foods.

After the product type is separated, the relationship is still relatively consistent that is significant and positive for traditional street foods $(\beta=.253, \mathrm{SE}$ $=.067, \mathrm{CR}=3.807)$ and modern street foods $(\beta=$ $.259 ; \mathrm{SE}=.072 ; \mathrm{CR}=3.586)$. Thus the hypothesis 3 is supported after the separation of product typr (Campbell 1999, Vaidyanathan \& Aggarwal 2003, Xia et al. 2004, Delafrooz \& Paim 2011; Harcar et al. 2012; Beneke et al. 2013). Otherwise, the relation between the fairness of price and intention to buy the street foods are not significant for traditional street foods $(\beta=.041 ; \mathrm{SE}=.038 ; \mathrm{CR}=1.072)$, but significant for modern street food $(\beta=.161 ; \mathrm{SE}=.066$; $\mathrm{CR}$ $=2.453)$. This means that in modern street foods, individual will consider the price in deciding to buy the street foods

\subsection{The Product Quality as Stimulus}

The relationship between the product quality and positive attitude toward street foods is significant and positive $(\beta=.255 ; \mathrm{SE}=.047$; $\mathrm{CR}=5.456)$. As well as the relationship between product price and intention to buy the street foods is significant and positive $(\beta=.083 ; \mathrm{SE}=.041 ; \mathrm{CR}=2.041)$. So the hypothesis 5 and hypothesis 6 are supported. It means the higher the perception of the product quality the higher the positive attitude towards street foods and intention to buy the street foods.

After the product type is separated, the relationship is still relatively consistent that is significant and positive for traditional street foods $(\beta=.221$; SE $=.061 ; \mathrm{CR}=3.617)$ and modern street foods $(\beta=$ $.286 ; \mathrm{SE}=.067 ; \mathrm{CR}=4,249)$. Thus the hypothesis 7 is supported after the separation of product type (Campbell 1999, Vaidyanathan \& Aggarwal 2003, Xia et al. 2004, Delafrooz \& Paim 2011, Harcar et al. 2012; Beneke et al. 2013). Furthermore, the relation between the fairness of price and intention to buy the street foods are not significant for traditional street foods $(\beta=.022 ; \mathrm{SE}=.033 ; \mathrm{CR}=.659)$, but significant and positive modern street foods $(\beta=$ $.115 ; \mathrm{SE}=.057 ; \mathrm{CR}=2.013)$. This means that in modern street foods, individual will consider yhe quality of product in deciding to buy the street foods, but it is not important consideration for traditional street foods.

\subsection{Easy in Obtaining the Foods as Stimulus}

The relationship between easy in obtaining the product and positive attitude toward street foods is not significant $(\beta=.075 ; \mathrm{SE}=.046 ; \mathrm{CR}=1.636)$. As well as the relationship between product price and intention to buy the street foods is not significant too $(\beta=.043 ; \mathrm{SE}=.044 ; \mathrm{CR}=.976)$. So the hypothesis 9 and hypothesis 10 are not supported.

After the product type is separated, the relationship is not consistent that is significant and positive for traditional street foods $(\beta=.128 ; \mathrm{SE}=.062 ; \mathrm{CR}$ $=2.061$ ) but not significant for modern street foods $(\beta=.076 ; \mathrm{SE}=.066 ; \mathrm{CR}=1.160)$. it means that individual will consider easy in obtaining the product in deciding the street foods, but this consideration is not importance for modern foods. The same phenomenon also occurs on the relationship between easy in obtaining the foods and intention to buy both for traditional street foods $(\beta=.055$; $\mathrm{SE}=.042$; $\mathrm{CR}=$ 1.313). or for modern street foods $(\beta=-.016$; $\mathrm{SE}=$ .063 ; $\mathrm{CR}=-.251)$. This means that for both of tradi- 
tional or modern street foods, easy in obtaining the food is not important in deciding to buy the street foods.

\subsection{The Relationship between Positive Attitude and Intention to buy the Street Food}

The relationship between positive attitude and intention to buy the street foods is significant and positive $(\beta=.386 ; \mathrm{SE}=.073 ; \mathrm{CR}=5.261)$. This relationship is consistent when the product type is separated into traditional $(\beta=.226 ; \mathrm{SE}=.079 ; \mathrm{CR}=3.863)$ and modern street foods $(\beta=.390 ; \mathrm{SE}=.095$; $\mathrm{CR}=$ 4.108). This suggests that the relationship between positive attitudes and intention to buy the product is consistent, which it means that if the individual has the positive attitude towards the product, it ultimately in turn affects on the intention to buy the product. So the hypothesis 13 is supported in this study.

\section{REFERENCES}

Ayres, I., \& Nalebuff, B. 2003. In praise of honest pricing. MIT Sloan Management Review 45 (1): 24-28.

Beneke, J., Flynn, R., Greig, T., \& Mukaiwa, M. 2013. The Influence of Perceived Product Quality, Relative Price and Risk on Costumer Value and Willingness to Buy: A Study of Private Label Merchandise. Journal of Product \& Brand Management 22(3): 218-228.

Bou, J.C. \& Satorra, A. 2010. A Multigroup Structural Equation Approach: A Demonstration by Testing Variation of Firm Profitability Across EU Samples. Organizational Research Methods 13: 738-766.

Campbell, M.C. 1999. Perceptions of price unfairness: antecedents and consequences. Journal of Marketing Research 36(1): 87-99.

Catoiu, I.A. Vranceanu, D.M. \& Filip, A. 2010. Setting fair price - fundamental principle sustainable marketing. Commerce Contribution to Sustainable Development 12(27): 115-128.

De-Matos, C.A., Ituassu, C.T., \& Rossi, C.A.V. 2007. Consumer Attitudes toward Counterfeits: A Review and Extension. Journal of Marketing 24 (1): 36-47.

Dehghanan, H., \& Bakhshandeh, G. 2014. The Impact of Green Perceived Value and Green Perceived Risk on Green Purchase Behavior of Iranian Consumers, International Journal of Management and Humanity Sciences 3(2): 1349-1357.

Delafrooz, N. \& Paim, L. 2011. An Integrated Research Framework to Understand Consumer's Internet Purchase Intention. International Conference on Sociality and Economics Development 10: 375-378.

Dodds, W.B., Monroe, K.B., Grewal, D. 1991. Effects of Price, Brand, and Store Information on Buvers Product Evaluations. Journal of Marketing research 28: 307-319.

Gofton, L. \& Ness, M. 1991. Twin trends: health and convenience in food change or who killed the lazy housewife. British Food Journal 93: 17-23.
Harcar, T. \& Yucelt, U. 2012. American Consumer's Attitudes towards Different Airline Companies Channels: A comparison of transaction Methods. Pasos 10(2): 59-68.

Haryanto, B. 2014. The Influence of Ecological Knowledge and Product Attributes in Forming Attitude and Intention to Buy Green Product. International Journal of Marketing Studies 6(2): 83-91.

Haryanto, B \& Budiman, S. 2016. The green brand marketing strategies that utilize word of mouth: Survey on green electronic products in Indonesia. Global Business and Financial Review 21(2):20-33.

Haryanto, B., Nusantara, A.C., \& Budiman, S. 2015. How Sexuality in Elegance of Advertising and Congruency of Product Influence Brand Evaluation? (The Study of Consumer Behavior using an Experimental Design Approach). Mediterranean Journal of Social Sciences 6(4): 118-129.

Kordnaeji, A., Askaripoor, H., \& Bakhshizadeh, A. 2013. Studying Affecting Factors on Customers Attitude toward Products with Halal Brand. International Research Journal of Applied and Basic Sciences 4(10): 3138-3145.

Mitchell, A. A. \& Olson, J. C. 1981. Are product attribute beliefs the only mediator of advertising effects on brand attitude? Journal of Marketing Research 18: $318-32$.

Mittal, V., Ross, W.T., Jr., \& Baldasare, P.M. 1998. The Asymmetric Impact of Negative and Positive Attribute-Level Performance on Overall Satisfaction and Repurchase Intentions. Journal of Marketing 62: 33-47.

Munger, J. L. \& Grewal, D. 2001. The Effects of Alternative Price Promotional Methods on Consumers' Product Evaluations and Purchase Intentions. Journal of Product and Brand Management 10(3): 185-197.

Nickols, S. Y., \& Fox, K. D. 1983. Buying time and saving time: Strategies for managing household production. Journal of Consumer Research 10: 197-208.

Scholderer, J., \& Grunert, K.G. 2005. Consumers, food and convenience: The long way from resource constraints to actual consumption patterns. Journal of Economic Psychology 26: 105-128.

Simonin, B.L. \& Ruth, J.A. 1998. Is company known by the company it keeps? Assessing the spillover effects of brand alliance on consumer brand attitudes. Journal of Marketing Research 16: 30-42.

Sulek, J. \& Hensley, R.L. 2004. The Relative Importance of Food, Atmosphere and Fairness of wait: The Case of a Full- service Restaurant. Cornell Hotel and Restaurant Administration Quarterly 45(3): 235-247.

Thom, N.T. 2007. Attitude, Motivation, and Consumption of seafood in Bachnich Province, Vietnam. Unpublished Master Thesis in International Fisheries Management. University of Troms $\varnothing$. Norwegia.

Torres, E. \& Kline, S.F. 2006. From customer satisfaction to delight: a model for the hotel industry. International Journal of Contemporary Hospitality Management 18(4): 290-301.

Vaidyanathan, R., \& Aggarwal, P., 2003. Who Is the Fairest of Them All? An Attributional Approach to Price Fairness Perceptions. Journal of Business Research 56(6): 453-463.

Van-Trijp, Hans C.M., Wayne D. Hoyer \& J. Jeffrey Inman. 1996. Why Switch? Product Category-Level Ex- 
planations for True Variety-Seeking Behavior. Journal of Marketing Research 33: 281 - 292.

Verlegh, P.W.J. \& Candel, M.J.J.M. 1999. The consumption of convenience foods: Reference groups and eating situations. Food Quality and Preference 10: 457464.

Weiss, R., Feinstein, A.H. \& Dalbor, M. 2004. Customer satisfaction of theme restaurant attributes and their influence on return intent. Journal of Food Service Business Research 7(2): 23-41.

Xia, L., Monroe, K.B., \& Cox, J.K., 2004. The price is unfair! a conceptual framework of price fairness perceptions. Journal of Marketing 68 (4): 1-15. 